\title{
Dual-Fluorescence L-Amino Acid Reports Insertion and Orientation of Melittin Peptide in Cell Membranes
}

\author{
Viktoriia Y. Postupalenko, ${ }^{\dagger}$ Oleksandr M. Zamotaiev, ${ }^{\ddagger}$ Volodymyr V. Shvadchak, ${ }^{\dagger}, \S$ Aleksandr V. Strizhak, ${ }^{\ddagger}$ \\ Vasyl G. Pivovarenko, Andrey S. Klymchenko, ${ }^{* \dagger}$ and Yves Mely ${ }^{\dagger}$ \\ ${ }^{\dagger}$ Laboratoire de Biophotonique et Pharmacologie, UMR 7213 CNRS, Université de Strasbourg, Faculté de Pharmacie, 74, Route du \\ Rhin, 67401 Illkirch Cedex, France \\ ${ }^{\ddagger}$ Department of Chemistry, Kyiv National Taras Shevchenko University, 01033 Kyiv, Ukraine \\ ${ }^{\S}$ Laboratory of Cellular Dynamics, Max Planck Institute for Biophysical Chemistry, am Fassberg 11, 37077 Göttingen, Germany
}

Supporting Information

ABSTRACT: Monitoring insertion and orientation of peptides in situ on cell membranes remains a challenge. To this end, we synthesized an L-amino acid (AFaa) containing a dualfluorescence dye of the 3-hydroxyflavone family, as a side chain. In contrast to other labeling approaches using a flexible linker, the $\mathrm{AFaa}$ fluorophore, introduced by solid phase synthesis into desired position of a peptide, is attached closely to its backbone with well-defined orientation, and, therefore, could reflect its localization in the membrane. This concept

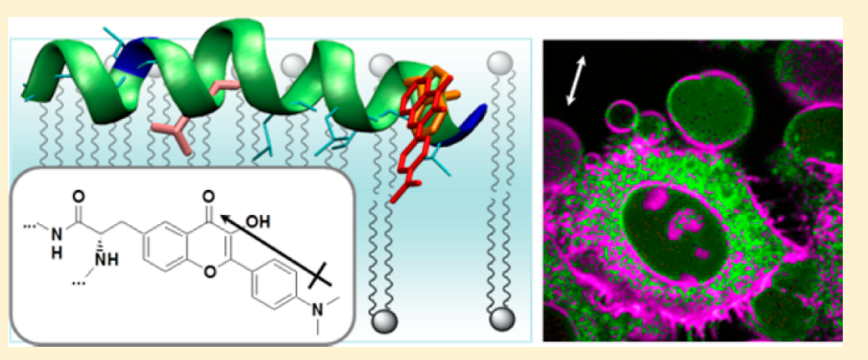
was validated by replacing the leucine-9 (L9) and tryptophan-

19 (W19) residues by AFaa in melittin, a well-studied membrane-active peptide. Due to high sensitivity of AFaa dual emission to the environment polarity, we detected a much deeper insertion of L9 peptide position into the bilayer, compared to the W19 position. Moreover, using fluorescence microscopy with a polarized light excitation, we found different orientation of AFaa at L9 and W19 positions of melittin in the bilayers of giant vesicles and cellular membranes. These results suggested that in the natural membranes, similarly to the model lipid bilayers, melittin is preferentially oriented parallel to the membrane surface. The developed amino acid and the proposed methodology will be of interest to study other membrane peptides.

\section{INTRODUCTION}

Membrane binding peptides and small proteins are involved in numerous important cellular processes including membrane fusion, disruption, or channel formation. Determination of peptide insertion depth and orientation in membranes is important for understanding the mechanisms and developing peptide-based drugs, transfecting reagents, and so forth. ${ }^{1}$

Numerous techniques were developed in vitro to characterize peptide-lipid membrane interactions, including isothermal titration calorimetry (thermodynamics), ${ }^{2}$ nuclear magnetic resonance (peptide structure), ${ }^{3,4}$ circular dichroism (conformation), ${ }^{5}$ electron spin resonance (immersion), ${ }^{6}$ and fluorescence (affinity, localization, etc.). ${ }^{7}$ For the last technique, environment-sensitive fluorescent probes allow measurements at low (physiological) peptide concentrations and provide fast response. $^{8}$ These probes are essential for experiments with natural cell membranes and constitute versatile tools for investigating the dynamics of peptide binding. ${ }^{9}$ Fluorescent probes incorporated into peptides should combine strong changes of their emission upon membrane binding with relatively small size in order to minimally perturb the peptide structure and report on the environment as close as possible to the peptide backbone. The classical bioconjugation strategies for fluorescent labeling of peptides are based on coupling of sulfhydryl- and amino-reactive dyes with cysteine ${ }^{10}$ and lysine ${ }^{11}$ amino acids, respectively. They were successfully applied to graft environment-sensitive dyes, such as NBD, ${ }^{12}$ Dansyl, ${ }^{13,14}$ and Prodan, ${ }^{15}$ to peptides for site-specific probing of the peptide-membrane interactions. However, with both bioconjugation strategies these dyes are attached to a peptide through a flexible linker that is at least $0.5 \mathrm{~nm}$ long, so that they are not positioned precisely at the site of labeling. ${ }^{16}$ In order to locate the probes closer to the peptide backbone ${ }^{17}$ and sitespecifically monitor the peptide environment, another strategy is to prepare fluorescent amino acid analogues, ${ }^{18-21}$ based on solvatochromic fluorophores like prodan ${ }^{22}$ or aminonaphtalimide. ${ }^{8,23}$

Though effective enough in the mentioned studies, these amino acids show limited spectroscopic properties and sensitivity to binding events. To overcome these drawbacks, recently we designed the first chiral L-amino acid based on a 2furyl-3-hydroxychromone fluorophore and applied it to sitespecifically probe peptide-nucleic acid interactions. ${ }^{24}$ Due to an excited state intramolecular proton transfer (ESIPT)

Received: July 14, 2013

Revised: October 1, 2013

Published: November 24, 2013 
reaction, ${ }^{25} 3$-hydroxychromone (3HC) and 3-hydroxyflavone (3HF) dyes show dual fluorescence with superior sensitivity to environment parameters such as polarity and hydration, since they combine solvatochromic shifts of normal $\left(\mathrm{N}^{*}\right)$ and tautomer $\left(\mathrm{T}^{*}\right)$ emission bands with changes of the ratio of these bands. ${ }^{26}$ Such a multiparametric sensing allows fine discrimination of environment of different types of membranes $^{27-30}$ as well as monitoring peptide-DNA ${ }^{24,31}$ and protein-protein interactions. ${ }^{32}$

In the present study, we focused on the $4^{\prime}$-(dimethylamino)3-hydroxyflavone fluorophore, as its environment-sensitivity is adapted to membrane research and its spectral properties are suited for microscopy studies. An L-amino acid AFaa bearing this fluorophore (Figure 1A) was constructed from natural

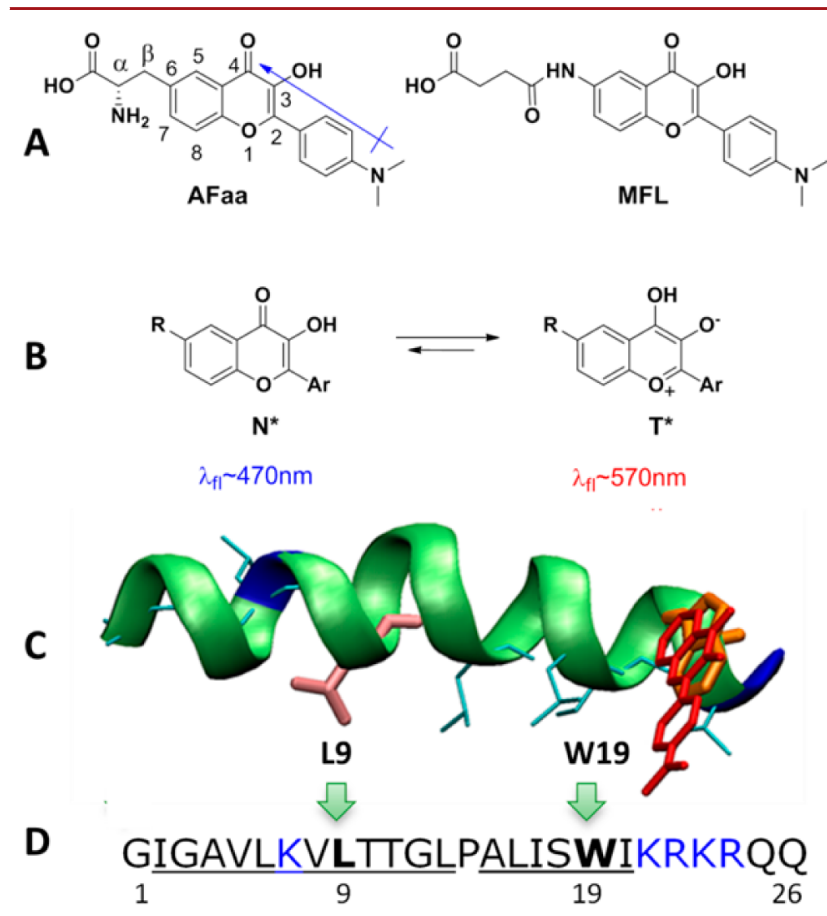

Figure 1. Fluorescent amino acid and labeling of melittin. (A) Structure of the 3-hydroxyflavone-based amino acid (AFaa) and label for amino groups (MFL). The blue arrow shows the direction of the transition dipole moment. ${ }^{33}$ (B) Excited state intramolecular proton transfer (ESIPT) reaction in 3-hydroxyflavones. (C) Structure of melittin based on NMR data (pdb 3QRX). ${ }^{34}$ Labeling sites L9 and W19 are in pink and orange, respectively. Five unstructured residues at the basic C-terminus are not shown. The structure of AFaa in red is overlaid with W19 for size comparison. (D) Sequence of melittin. The arrows show the two alternative positions where the natural amino acids were replaced by the AFaa amino acid. Residues forming membrane-bound $\alpha$-helix are underlined; cationic amino acids are in blue.

tyrosine to allow close location of the fluorophore to the peptide backbone. The fluorophore moiety of AFaa is similarly lipophilic as the indole unit of tryptophan and should thus mimic its localization and orientation in the lipid membrane.

As a model peptide for testing the new fluorescent amino acid, we selected melittin, a well-described cationic membranebinding peptide, corresponding to the main toxic component of European honey bee venom. ${ }^{35}$ It is composed of 26 amino acids that are predominantly hydrophobic, but contains a stretch of positively charged amino acids at the C-terminal domain (Figure 1). Melittin is soluble in water and adopts predominantly a random coil conformation, while it selfassociates into $\alpha$-helical tetramers at high ionic strength or high peptide concentration. ${ }^{35}$

Melittin spontaneously binds to natural and artificial membranes, adopting an $\alpha$-helical conformation. ${ }^{36}$ Interestingly, depending on the membrane properties and lipid-toprotein ratio, melittin was reported to be transmembrane ${ }^{37}$ or to orient parallel to membrane surface. ${ }^{38,39}$ Melittin as an active component of honey bee venom induces the leakage of cellular content. Some authors suggest that this process is the result of formation of pores with transmembrane orientation of the peptide. $^{40}$ The others show that the relatively high peptide to lipid ratios $(>1: 200)$ are needed for its membrane permeabilization activity, which is more consistent with its binding parallel to the membrane surface. ${ }^{41}$ In our previous work, we labeled the $\mathrm{N}$-terminus of melittin with $4^{\prime}$-dimethylamino-3hydroxyflavone label (MFL, Figure 1A), which allowed us monitoring its binding and insertion into model membranes. However, these studies were limited to the probing of the environment of the peptide $\mathrm{N}$-terminus. Moreover, the spacer used to attach the probe made the analysis of the peptide orientation in the bilayer imprecise. ${ }^{28}$

In the present work, based on the same fluorophore, we synthesized the fluorescent amino acid AFaa and substituted it for the hydrophobic residues leucine-9 (L9) and tryptophan-19 (W19), middle and end of $\alpha$-helical domain of melittin, respectively. This allowed us to determine the insertion depth and orientation of melittin in model and cell membranes.

\section{MATERIALS AND METHODS}

Instrumentation. Proton NMR spectra were recorded on a $300 \mathrm{MHz}$ Bruker spectrometer, and mass spectra were recorded on a Mariner System 5155 mass spectrometer using the electrospray ionization (ESI) method. All chemicals and solvents for synthesis and spectroscopic measurements were from Sigma-Aldrich.

Amino Acid Synthesis. The synthesis of the 3-acetyl-Ltyrosine hydrochloride (1) and 3-acetyl- $\mathrm{N}$-(tert-butoxycarbonyl)-L-tyrosine (2) was performed as described previously. ${ }^{42,43}$

$\mathrm{N}$-(tert-Butoxycarbonyl)-3-(3-[4-(dimethylamino)phenyl]prop-2-enoyl)-L-tyrosine (3). $5.00 \mathrm{~g}$ (15.48 mmol) of 3-acetyl$\mathrm{N}$-Boc-L-tyrosine 2 were dissolved in $50 \mathrm{~mL}$ of ethanol upon stirring under Ar-atmosphere. Then, $50 \mathrm{~mL}$ of degassed $25 \%$ solution of sodium hydroxide were slowly added to the reaction mixture (cold water bath). After that, $4.00 \mathrm{~g}$ of 4dimethylaminobenzaldehyde (26.81 mmol, 1.73 equiv) were added and the mixture was stirred for $12 \mathrm{~h}$ at room temperature under Ar. Additional $0.52 \mathrm{~g}$ of aldehyde were added and the mixture was stirred overnight. Reaction was monitored by TLC $\left(\mathrm{CH}_{2} \mathrm{Cl}_{2}: \mathrm{MeOH}, 7: 3 \mathrm{v} / \mathrm{v}\right)$. For that, small aliquots were carefully acidified with $\mathrm{HCl}$ and extracted with ethyl acetate. Then, the orange mixture was carefully acidified with $\mathrm{HCl}$ and diluted twice with water. The obtained oil was separated, dissolved in $\mathrm{CH}_{2} \mathrm{Cl}_{2}$, washed with water, dried with $\mathrm{MgSO}_{4}$, and the solvent was evaporated in vacuo. The obtained oil was crystallized upon standing overnight under petroleum ether. Orange crystals were recrystallized from toluene/petroleum ether mixture. Yield $5.48 \mathrm{~g}(78 \%)$ of 3 as an orange powder. Mass spectroscopy, ion polarity - negative, $m / z$ : 453.2 $[\mathrm{M}-\mathrm{H}]^{-}$; ion polarity - positive, $m / z: 455.2[\mathrm{M}+\mathrm{H}]^{+} .{ }^{1} \mathrm{H}$ NMR (300 MHz, DMSO- $\left.d_{6}\right): \delta 1.25$ (s, 9H, Boc), $3.00(\mathrm{~s}, 6 \mathrm{H}$, $\left.\mathrm{N}\left(\mathrm{CH}_{3}\right)_{2}\right), 3.07-3.17\left(\mathrm{~m}, 2 \mathrm{H}, \mathrm{CH}_{2}\right), 4.09(\mathrm{~m}, 1 \mathrm{H}, \mathrm{CH}), 6.78$ (d, $2 \mathrm{H}, J=9 \mathrm{~Hz}, \mathrm{ArH}), 7.19$ (m, 1H, ArH), 7.45 (d, 2H, $J=9$ 
$\mathrm{Hz}, \mathrm{ArH}$ ), 7.53 (d, $1 \mathrm{H}, J=15 \mathrm{~Hz}, \mathrm{CH}$ ), 7.57 (br. s, $1 \mathrm{H}, \mathrm{Ph}-$ $\mathrm{OH}), 7.62$ (m, 2H, ArH), 7.91 (d, 2H, J = $15 \mathrm{~Hz}, \mathrm{CH}), 9.05$ (br. s, $1 \mathrm{H}, \mathrm{NH}$ ), 12.78 (br. s, $1 \mathrm{H}, \mathrm{COOH}$ ).

$\mathrm{N}$-(tert-Butoxycarbonyl)-3-(2-[4-(dimethylamino)phenyl]3-hydroxy-4-oxo-4H-chromen-6-yl)-L-alanine (4). $5.00 \mathrm{~g}$ $(11.00 \mathrm{mmol})$ of chalcone 3 was dissolved in $60 \mathrm{~mL}$ of ethanol, cooled in ice bath, and $44 \mathrm{~mL}$ of $1 \mathrm{M}$ solution of sodium hydroxide was carefully added with stirring. After that, $2.9 \mathrm{~mL}$ of $30 \%$ hydrogen peroxide was added carefully and the mixture was stirred in ice bath for approximately $6 \mathrm{~h}$ under Aratmosphere. The reaction was monitored by TLC $\left(\mathrm{CH}_{2} \mathrm{Cl}_{2}: \mathrm{MeOH}(8: 2 \mathrm{v} / \mathrm{v})\right.$. Then the reaction mixture was diluted with $200 \mathrm{~mL}$ of ether, acidified with conc. $\mathrm{HCl}$ to $\mathrm{pH} 2$ and the obtained orange precipitate was filtered and washed with water. Yield of the crude 3-hydroxychromone 4 was $3.55 \mathrm{~g}$. It was purified by crystallization from methanol/water (4:1) mixture. Yield $1.7 \mathrm{~g}$ (33\%) of yellow crystals. Mass spectroscopy, ion polarity - negative, $m / z: 467.0[\mathrm{M}-\mathrm{H}]^{-}$; ion polarity - positive. $m / z: 469.0[\mathrm{M}+\mathrm{H}]^{+}$. ${ }^{1} \mathrm{H}$ NMR (300 MHz, DMSO$\left.d_{6}\right): \delta 1.28(\mathrm{~s}, 9 \mathrm{H}, \mathrm{Boc}), 3.01\left(\mathrm{~s}, 6 \mathrm{H}, \mathrm{N}\left(\mathrm{CH}_{3}\right)_{2}\right), 3.14(\mathrm{~m}, 2 \mathrm{H}$, $\left.\mathrm{CH}_{2}\right), 4.15(\mathrm{~m}, 1 \mathrm{H}, J=3 \mathrm{~Hz}, \mathrm{CH}), 6.83(\mathrm{~d}, 2 \mathrm{H}, J=9 \mathrm{~Hz}$, $\operatorname{ArH}), 7.19$ (d, 1H, J = 9 Hz, ArH), 7.64 (m, 2H, ArH), 7.95 (br. s, $1 \mathrm{H}, \mathrm{OH}), 8.11$ (d, $2 \mathrm{H}, J=9 \mathrm{~Hz}, \mathrm{ArH}$ ), 9.14 (br. s, $1 \mathrm{H}$, $\mathrm{NH}), 12.66$ (br. s, 1H, COOH).

3-(2-[4-(Dimethylamino)phenyl]-3-hydroxy-4-oxo-4Hchromen-6-yl)-L-alanine hydrochloride (5). $1.14 \mathrm{~g}$ (2.43 $\mathrm{mmol}$ ) of chromone 4 was dissolved in $14 \mathrm{~mL}$ of dioxane and after that, $14 \mathrm{~mL}$ of conc. $\mathrm{HCl}$ was added with cooling the reaction mixture in an ice water bath. After $10 \mathrm{~min}$, the bath was removed and the mixture was stirred for 2-3 h under Aratmosphere. Then, it was evaporated under reduced pressure. Yield $0.896 \mathrm{~g}$ (91\%) of dark yellow hygroscopic powder. Mass spectroscopy, ion polarity - negative, $m / z: 367.0[\mathrm{M}-\mathrm{H}]^{-}$; ion polarity - positive, $\mathrm{m} / z: 369.0[\mathrm{M}+\mathrm{H}]^{+}$. Corresponds to the free base, $\mathrm{M}=368.4$. ${ }^{1} \mathrm{H}$ NMR (300 MHz, DMSO- $d_{6}$ ): $\delta 3.04$ (s, $\left.6 \mathrm{H}, \mathrm{N}\left(\mathrm{CH}_{3}\right)_{2}\right), 3.29\left(\mathrm{dd}, 2 \mathrm{H}, J=4.2 \mathrm{~Hz}, J=3 \mathrm{~Hz}, \mathrm{CH}_{2}\right)$, $4.26(\mathrm{q}, 1 \mathrm{H}, J=3 \mathrm{~Hz}, \mathrm{CH}), 6.91(\mathrm{~d}, 2 \mathrm{H}, J=8 \mathrm{~Hz}, \operatorname{ArH}), 7.69$ (dd, $1 \mathrm{H}, J=6 \mathrm{~Hz}, J=3 \mathrm{~Hz}, \operatorname{ArH}), 7.73(\mathrm{~d}, 1 \mathrm{H}, J=6 \mathrm{~Hz}, \mathrm{ArH})$, 8.01 (d, $1 \mathrm{H}, J=3 \mathrm{~Hz}, \mathrm{ArH}), 8.14$ (d, $2 \mathrm{H}, J=8 \mathrm{~Hz}, \operatorname{ArH}), 8.44$ (br. s, $\left.3 \mathrm{H}, \mathrm{NH}_{3}^{+}\right)$.

3-(2-[4-(Dimethylamino)phenyl]-3-hydroxy-4-oxo-4Hchromen-6-yl)- $\mathrm{N}$-[(9H-fluoren-9-ylmethoxy) carbonyl]-L-alanine (6, Fmoc-AFaa). $600 \mathrm{mg}$ (1.48 mmol) of chlorohydrate of amino acid 5 was dissolved in a solution of $500 \mathrm{mg}(5.95$ $\mathrm{mmol}$ ) of sodium bicarbonate in $20 \mathrm{~mL}$ of water. Subsequently, $30 \mathrm{~mL}$ of DMF was added. Then, $500 \mathrm{mg}$ ( 1 equiv) of FmocOSu was added and the mixture was stirred for $24 \mathrm{~h}$ under Ar-atmosphere. After that, the mixture was diluted with $20 \mathrm{~mL}$ of water and the precipitate of sodium salt of the crude product was filtered. Finally, it was purified by dissolution of the sodium salt in hot water (about $100 \mathrm{~mL}$ per $1 \mathrm{~g}$ ) and further acidification with $\mathrm{HCl}$. Yield $640 \mathrm{~g}$ (73\%), orange powder. Mass spectroscopy, ion polarity - positive, $\mathrm{m} / \mathrm{z}: 591.0$ $[\mathrm{M}+\mathrm{H}]^{+}$. ${ }^{1} \mathrm{H}$ NMR $\left(300 \mathrm{MHz}, \mathrm{DMSO}-d_{6}\right): \delta 3.01(\mathrm{~s}, 6 \mathrm{H}$, $\left.\mathrm{N}\left(\mathrm{CH}_{3}\right)_{2}\right), 3.25\left(\mathrm{~m}, 2 \mathrm{H}, \mathrm{CH}_{2}\right), 4.17\left(\mathrm{~m}, 2 \mathrm{H}, \mathrm{CH}_{2}\right), 4.26(\mathrm{~m}$, $1 \mathrm{H}, \mathrm{CH}), 6.85$ (d, 2H, J = 9 Hz, ArH), 7.25 (m, 2H, ArH), 7.36 (m, 3H, ArH), 7.58 (m, 2H, ArH), 7.65 (m, 2H, ArH), 7.79 (s, $1 \mathrm{H}, \mathrm{ArH}), 7.84$ (d, $2 \mathrm{H}, J=8 \mathrm{~Hz}, \mathrm{ArH}), 8.01$ (br. s, $1 \mathrm{H}, \mathrm{OH}$ ), $8.11(\mathrm{~d}, 2 \mathrm{H}, J=9 \mathrm{~Hz}, \mathrm{ArH}), 9.13$ (br. s, $1 \mathrm{H}, \mathrm{NH}$ ), 12.79 (br. s, $1 \mathrm{H}, \mathrm{COOH})$.

Peptide Synthesis, Labeling, and, Purification. Nterminally labeled MFL-melittin was synthesized as described previously. ${ }^{28}$ Melittin peptides, where L9 and W19 residues were replaced by AFaa, were synthesized by solid phase peptide synthesis on a 433A synthesizer (ABI, Foster City, CA). The synthesis was performed at a $0.1 \mathrm{mmol}$ scale using standard side-chain protected fluorenylmethoxycarbonyl (Fmoc)-amino acids and HBTU/HOBt coupling protocol. LL-amide resin (54 $\mathrm{mmol} / \mathrm{g}$ reactive group concentrations) was used as a solid support.

Coupling of the fluorescent AFaa amino acid was performed manually, in $10 \mathrm{~mL}$ flask using the same coupling solution as for automated synthesis. In our experiments, we used only a 2fold excess of the AFaa over the peptidyl resin (comparing with 10 -fold for other amino acids). Therefore, we increased the coupling time to $2 \mathrm{~h}$ (comparing with $20 \mathrm{~min}$ ) and added the labeled amino acid in two steps ("double coupling") to minimize formation of peptide lacking the labeled residue. To ensure that no deletion product could form, we capped the unreacted N-terminal amino groups with acetic anhydride. At the end of the synthesis, the peptidyl resin was isolated and washed twice by NMP.

Cleavage and deprotection of the peptidyl resin were performed for $2 \mathrm{~h}$ using a $10 \mathrm{~mL}$ trifluoroacetic acid (TFA) solution containing water $(5 \%, \mathrm{v} / \mathrm{v})$, TIS $\left(\mathrm{iPr}_{3} \mathrm{SiH}, 2.5 \%, \mathrm{v} / \mathrm{v}\right)$, thioanisole $(5 \%, \mathrm{v} / \mathrm{v})$, and ethanedithiol $(2.5 \%, \mathrm{v} / \mathrm{v})$. During the deprotection step, common scavengers used to protect Lys or Arg (such as $\mathrm{iPr}_{3} \mathrm{SiH}$ ) residues were added to prevent the AFaa fluorophore to undergo ring-opening reactions. The solution was concentrated in vacuo and the peptide was precipitated by ice-cold diethyl ether and, then, pelleted by centrifugation. The pellet was washed with diethyl ether and dried. The peptides were solubilized with aqueous TFA (0.05\%, $\mathrm{v} / \mathrm{v})$. HPLC purification was carried out on a C8 column (uptisphere $300 \mathrm{~A}, 5 \mu \mathrm{m} ; 250 \times 10$, Interchim, France) in a water/acetonitrile mixture containing $0.05 \%$ TFA with linear gradients depending on the peptide: for L9, 30-60\% acetonitrile in $40 \mathrm{~min}$; and for W19, 40-60\% acetonitrile in $30 \mathrm{~min}$. Molecular masses obtained by ion spray mass spectrometry were as follows: 3082.79 for L9; 3009.79 for W19, in agreement with the expected theoretical masses. Prior to use, peptides were dissolved in distilled water, aliquoted, and stored at $-20{ }^{\circ} \mathrm{C}$. Concentrations of the labeled peptides were determined using the label absorbance at $400 \mathrm{~nm}(\varepsilon=33000$ $\left.\mathrm{M}^{-1} \mathrm{~cm}^{-1}\right)$.

Fluorescence Measurements. Absorption spectra were measured on a Cary 4000 spectrophotometer (Varian) and fluorescence spectra on a FluoroLog (JobinYvon, Horiba) spectrofluorometer. Fluorescence emission spectra were recorded at $400 \mathrm{~nm}$ excitation wavelength in $20 \mathrm{mM}$ phosphate buffer containing $150 \mathrm{mM} \mathrm{NaCl}(\mathrm{pH}=7.4)$ at $20^{\circ} \mathrm{C}$. All the spectra were corrected for Raman scattering and background fluorescence. Fluorescence quantum yields were determined using 4'-(diethylamino)-3-hydroxyflavone in ethanol (quantum yield 0.52$)^{44}$ as a reference. Deconvolution of the fluorescence spectra of the labeled peptides into three bands, corresponding to the normal $\left(\mathrm{N}^{*}\right)$, H-bonded normal $\left(\mathrm{H}-\mathrm{N}^{*}\right)$ and tautomer $\left(\mathrm{T}^{*}\right)$ forms, was performed using the Siano software kindly provided by Dr. A.O. Doroshenko (Kharkov, Ukraine), as previously described. $^{28,45}$ The individual emission bands were approximated by a log-normal function accounting for several parameters: maximal amplitude, $I_{\max }$, spectral maximum position, $\nu_{\max }$ and position of half-maximum amplitudes, $\nu_{1}$ and $\nu_{2}$, for the blue and red parts of the band, respectively. These parameters determine the shape parameters of the lognormal function, namely, the full width at the half-maximum, 
fwhm $=\nu_{1}-\nu_{2}$, and the band asymmetry, $P=\left(\nu_{1}-\nu_{\max }\right) /$ $\left(\nu_{\max }-\nu_{2}\right)$. For the iteration process, the fwhm of the two short-wavelength bands $\left(\mathrm{N}^{*}\right.$ and $\left.\mathrm{H}-\mathrm{N}^{*}\right)$ were fixed at 3000 $\mathrm{cm}^{-1}$. For the $\mathrm{H}-\mathrm{N}^{*}$ band, the asymmetry and the band position were fixed at 0.9 and $18400 \mathrm{~cm}^{-1}$, respectively. The other parameters were allowed to vary in the iteration process. The resulting fluorescence intensities of the separated $\mathrm{N}^{*}$ and $\mathrm{T}^{*}$ bands were used to calculate the $\mathrm{N}^{*} / \mathrm{T}^{*}$ ratio.

Large Unilamellar Vesicles. Large unilamellar vesicles (LUVs) of $\sim 100 \mathrm{~nm}$ diameter (according to dynamic light scattering, DLS) were obtained by the classical extrusion method as previously described: ${ }^{45}$ evaporation of chloroform solution of lipids, hydration of the resulted film in buffer, and ten extrusions of the obtained solution through membrane with $100 \mathrm{~nm}$ pores. Small unilamellar vesicles (SUVs) for CD spectroscopy were prepared by ultrasonication ( $\sim 0 \mathrm{~min}, 20$ ${ }^{\circ} \mathrm{C}$ ) of the lipid suspension with size distribution control by DLS $(45 \pm 7 \mathrm{~nm})$.

Giant Unilamellar Vesicles. Giant unilamellar vesicles (GUVs) were generated by electroformation in a home-built liquid cell, using previously described procedures. ${ }^{46,47} 1 \mathrm{mM}$ solution of lipids in chloroform was deposited on the platinum wires of the chamber, and the solvent was evaporated under vacuum for $30 \mathrm{~min}$. The chamber was filled with a $300 \mathrm{mM}$ sucrose solution, and a $2 \mathrm{~V}, 10 \mathrm{~Hz}$ alternating electric current was applied to this capacitor-like configuration for ca. $1.5 \mathrm{~h}$. Then, a $50 \mu \mathrm{L}$ aliquot of the obtained stock solution of GUVs in sucrose was added to $200 \mu \mathrm{L}$ of $300 \mathrm{mM}$ glucose solution to give the final suspension of GUVs used in microscopy experiments. Staining of GUVs was performed by addition of an aliquot of the peptide solution to obtain a $0.2 \mu \mathrm{M}$ final concentration.

Cell Preparation and Staining. HeLa cells were cultured in Dulbecco's modified Eagle medium (DMEM, high glucose, Gibco-Invitrogen) supplemented with $10 \%(\mathrm{v} / \mathrm{v})$ fetal bovine serum (FBS, Lonza), 1\% antibiotic solution (penicillinstreptomycin, Gibco-Invitrogen) in a humidified incubator with $5 \% \mathrm{CO}_{2}$ atmosphere at $37^{\circ} \mathrm{C}$. A cell concentration of (510) $\times 10^{4}$ cells $/ \mathrm{mL}$ was maintained by removal of a portion of the culture and replacement with fresh medium, three times per week. For microscopy studies, cells were seeded onto a chambered coverglass (IBiDi) at a density of $5 \times 10^{4}$ cells/ IBiDi. After washing the cells with Opti-MEM, a solution of labeled melittin diluted in $1 \mathrm{~mL}$ of Opti-MEM was added to the cells to a final concentration of $1 \mu \mathrm{M}$ and immediately measured.

Microscopy. Fluorescence microscopy experiments were performed by using a home-built two-photon laser scanning setup based on an Olympus IX70 inverted microscope with an Olympus $60 \times 1.2 \mathrm{NA}$ water immersion objective. ${ }^{48}$ Twophoton excitation at $830 \mathrm{~nm}$ was provided by a titaniumsapphire laser (Tsunami, Spectra Physics). A density filter of 0.2 was used on the red channel. Images corresponding to the blue and red channels were recorded simultaneously using a dichroic mirror at $555 \mathrm{~nm}$ and two APDs. The images were processed with LabView-based (for GUVs) or ImageJ-based (for cells) programs that generate a ratiometric image by dividing the image of the blue channel by that of the red channel. ${ }^{47,49}$ For each pixel, a pseudocolor scale is used for coding the ratio, while the intensity is defined by the integrated intensity recorded for both channels at the corresponding pixel.

\section{RESULTS AND DISCUSSION}

Design and Synthesis. The Fmoc-protected fluorescent Lamino acid Fmoc-AFaa was designed by extending the side chain of L-tyrosine into a 3-hydroxyflavone group bearing an electron-donating dimethylamino group (Scheme 1). The

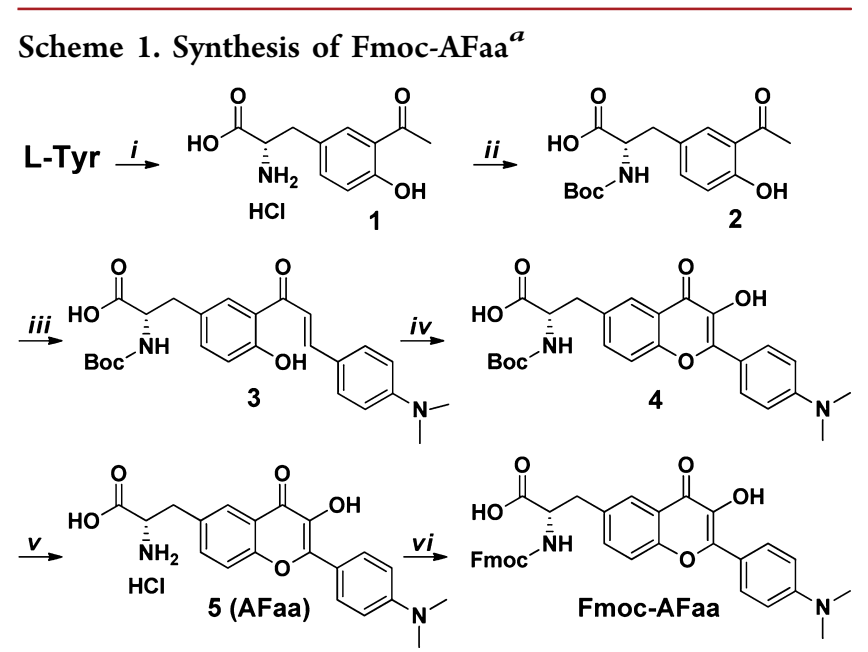

a(i) $\mathrm{AcCl}, \mathrm{AlCl}_{3}, \mathrm{PhNO}_{2}$; (ii) $\mathrm{Boc}_{2} \mathrm{O}$; (iii) 4-dimethylaminobenzaldehyde, $\mathrm{NaOH}, \mathrm{EtOH} / \mathrm{H}_{2} \mathrm{O}$; (iv) $\mathrm{H}_{2} \mathrm{O}_{2}, \mathrm{NaOH}, \mathrm{EtOH}$; (v) $\mathrm{HCl}$, dioxane; (vi) FmocOSu, $\mathrm{NaHCO}_{3}, \mathrm{DMF} / \mathrm{H}_{2} \mathrm{O}$.

lipophilicity of AFaa is close to the one of tryptophan (calculated $\log \mathrm{P}$ values are equal to 0.48 and 0.11 , respectively). Moreover, the side chain of the AFaa amino acid is only $\sim 0.5$ $\mathrm{nm}$ longer than the tryptophan indole ring, and the distance from the fluorophore to the peptide backbone is $0.2-0.7 \mathrm{~nm}$ (Figure S1), which is less than the diameter of $\alpha$-helix. All these features ensure a better site-specific probing of the environment than the cysteine labeling approach $(>1 \mathrm{~nm}$ distance from the backbone). Similarly to natural aromatic amino acids, the rotation of $\mathrm{AFaa}$ fluorophore with respect to the peptide backbone is limited to $\mathrm{C}_{\alpha}-\mathrm{C}_{\beta}$ and $\mathrm{C}_{\beta}-\mathrm{C}_{6}$ bonds. Thus, the rotational freedom around $\mathrm{C}_{\alpha}-\mathrm{C}_{\beta}$ bond should be as for tyrosine and tryptophan in native peptides ${ }^{50}$ with the preference for trans-conformation of the aromatic residue relative to the carbonyl in their $\alpha$-helix. A key feature is that the orientation of the transition dipole of the AFaa fluorophore is parallel to its rotation axis $\left(\mathrm{C}_{\beta}-\mathrm{C}_{6}\right.$ bond, Figure 1$)$, which decreases the uncertainty of the dye dipole orientation in respect to the peptide and, thus, allows the determination of the peptide orientation by the orientation of the AFaa fluorophore.

Fmoc-protected fluorescent L-amino acid Fmoc-AFaa was prepared from L-tyrosine according to the strategy we described earlier for other fluorescent amino acid. ${ }^{24}$ Synthesis of Fmoc$\mathrm{AFaa}$ was done through tyrosine $\mathrm{C}$-acylation, Boc-protection, and condensation of the resulted product (2) with aldehyde into N-Boc-protected 2'-hydroxychalcone (3). Then, oxidative cyclization in basic conditions into N-Boc-protected-3-hydroxyflavone (4) was performed, followed by the change of the protective group to Fmoc (Scheme 1).

In the preparation of AFaa, none of the reaction steps include the asymmetry center conversion, but the steps (iii) and (iv) require application of alkali. Therefore, to check the optical purity of the obtained amino acid, we synthetized the amide derivatives of (5) with (R)- and (S)- $\alpha$-phenyl-ethylamine (Figure S2). The obtained diastereoisomers show differences in ${ }^{1} \mathrm{H}$-NMR-spectra (Figure S3 and discussion in SI) and 
comparison of peak intensities of the unpurified $(S, R)$ - and $(\mathrm{S}, \mathrm{S})$-amides shows that racemization is less than $10 \%$.

Synthesis and Structure of Melittin Fluorescent Variants. Melittin variants labeled by AFaa amino acids at positions L9 and W19 were synthesized according to typical Fmoc SPPS protocols. Coupling of Fmoc AFaa amino acid was done using a 2 -fold excess and $2 \mathrm{~h}$ reaction time. The $3-\mathrm{OH}$ group of AFaa was not protected, because being acylated by amino acid or acetic anhydride, it was easily recovered at the conditions of peptide cleavage from the resin. We saw no signs of AFaa decomposition on HPLC profile of the crude peptides. Melittin peptide labeled at the $\mathrm{N}$-terminus with MFL label was prepared as described previously. ${ }^{28}$

To check the influence of the introduction of the fluorescent amino acid on the affinity of melittin to lipid membranes, we titrated the labeled melittin peptides with POPC liposomes and monitored the increase in $\alpha$-helix content by CD spectroscopy at $222 \mathrm{~nm}$ (Figure S4). The labeled peptides show binding profiles similar to the one reported for unmodified melittin (Figure S4), ${ }^{50,51}$ indicating that substitution of either L9 or W19 by AFaa does not significantly perturb the peptide conformation and its membrane binding affinity.

Fluorescent Properties of AFaa and the Labeled Peptides in Solution. The AFaa amino acid shows a strong dependence of its dual emission on solvent polarity and its fluorescence is strongly quenched in aqueous media. These properties are similar to those of the MFL label ${ }^{28}$ and can thus be used to report on the local environment of the labeled sites of melittin.

Being diluted in buffer solution to a final concentration 0.3 $\mu \mathrm{M}$, all labeled peptides show complex time-dependent behavior, as their fluorescence intensity strongly decreases with time and the spectral shape changes. Indeed, for the $\mathrm{N}$ terminal labeled melittin (Figure 2A) and W19-substituted

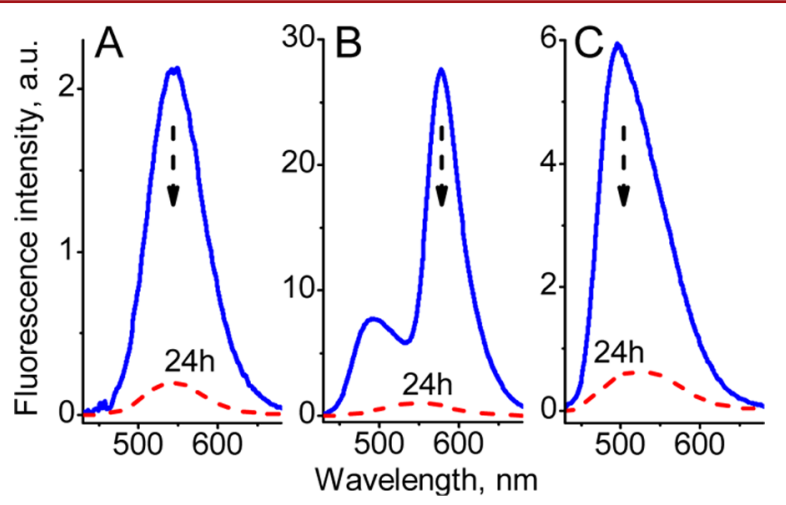

Figure 2. Changes of fluorescence spectra upon dissociation of melittin oligomers: N-terminal labeled melittin (A), L9 (B) and W19 (C) labeled variants. Time after preparation: $2 \mathrm{~min}$ (blue lines) or $24 \mathrm{~h}$ (red lines). Peptide concentration was $300 \mathrm{nM}$, phosphate buffer $\mathrm{pH}$ 7.2, $150 \mathrm{mM} \mathrm{NaCl}, 25^{\circ} \mathrm{C}$.

peptide (Figure 2C), the single band, which can be assigned to the $\mathrm{N}^{*}$ emission shifts to the red, while for L9-substituted melittin the dual emission degrades into single red-shifted $\mathrm{N}^{*}$ band (Figure 2B). The spectroscopic changes observed for all three peptides clearly suggest the strong increase in the polarity and hydration of the probe environment, which can only be explained by the dissociation of the melittin aggregates after their dilution in the buffer from the concentrated aqueous stock solution of $\sim 100 \mu \mathrm{M}$. Indeed, in the concentrated solution melittin molecules are reported to be in the form of tetramers, ${ }^{35}$ while after dilution in the buffer to micromolar concentration, they dissociate giving monomeric species, presenting much higher exposure of the $3 \mathrm{HF}$ dye to bulk water. It should be noted, in oligomeric melittin (spectra recorded immediately after dilution), the label at position W19 and $\mathrm{N}$-terminus show a single band emission typical for highly hydrated media, while at position L9 it shows two well separated emission bands, reporting nonpolar aprotic environment, in agreement with the previously described structure of tetramer ${ }^{51}$ where L9 segment of peptide is screened from water, while the other labeled positions are more exposed.

Probing Peptide-Membrane Interactions. Melittin efficiently binds to natural and model membranes. Interaction of the labeled peptides with DOPC vesicles results in the appearance of two emission bands typical for nonpolar media and a strong (up to 20-fold) increase in their fluorescence intensity (Figure 3A), in line with an immersion of the label in

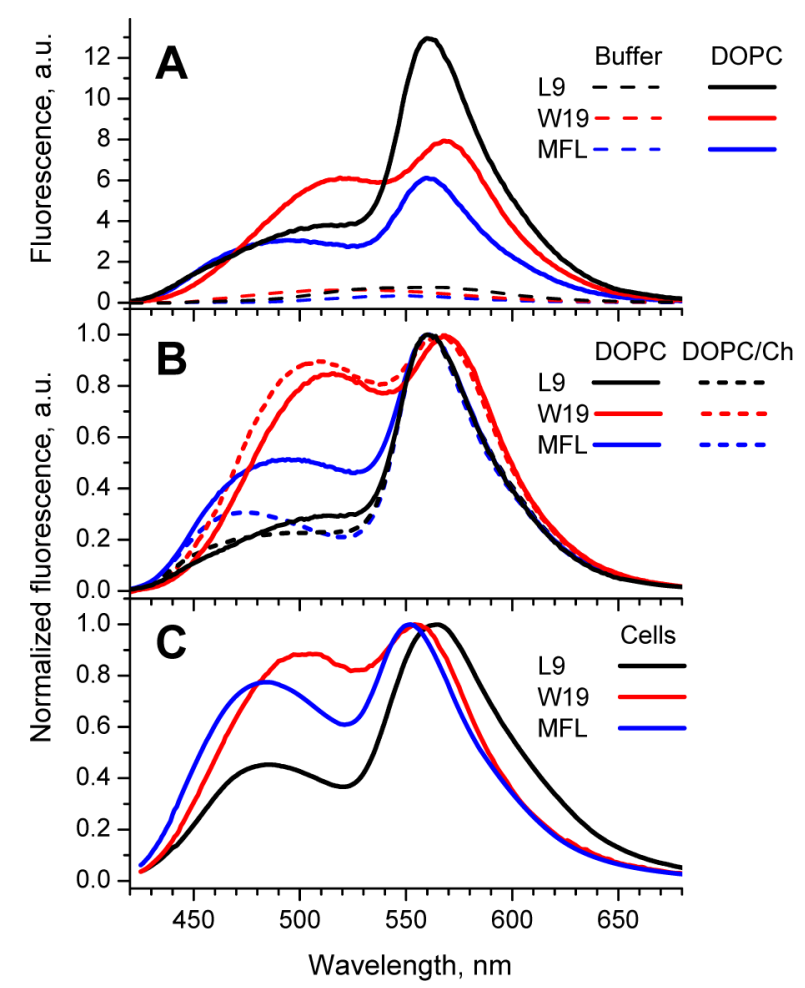

Figure 3. Probing peptide-membrane interactions, using labeled melittin peptides. (A) Fluorescence spectra of N-terminal, L9- and W19-labeled melittin peptides in buffer (dash) and DOPC vesicles (solid lines) at lipid $/$ peptide $(\mathrm{L} / \mathrm{P})$ ratio $=250 / 1$. (B) Normalized emission spectra of peptides in DOPC (solid lines) and DOPC:Cholesterol (6:4) (dashed lines) vesicles. Concentration of melittin and lipids was $300 \mathrm{nM}$ and $15 \mu \mathrm{M}$, respectively. (C) Normalized emission spectra of peptides bound to live cells. $300 \mathrm{nM}$ of melittin variants were added to HeLa cell suspensions and recorded after 2 min incubation.

the hydrophobic viscous medium of the membrane. Due to these strong changes in the fluorescence intensity, the fluorescence of free peptide is negligibly small, so that only the bound form contributes for the fluorescence spectra in the presence of vesicles.

The spectral profiles of the three peptide variants differ greatly in DOPC vesicles, indicating that the insertion of the $3 \mathrm{HF}$ fluorophore in lipid membranes depends on its position in 
melittin. Using previously established deconvolution of the spectra into three bands $\left(\mathrm{N}^{*}\right.$, hydrated $\mathrm{H}-\mathrm{N}^{*}$, and $\left.\mathrm{T}^{*}\right)$, we estimated the $\mathrm{N}^{*} / \mathrm{T}^{*}$ intensity ratio, the parameter that correlates directly with the dielectric constant of the environment. ${ }^{28}$ AFaa at position L9 shows the lowest $\mathrm{N}^{*} / \mathrm{T}^{*}$ band ratio (0.27), which corresponds to the dielectric constant $\varepsilon \approx 5$. According to the dielectric model of lipid bilayer suggested by Griffith et al., ${ }^{52}$ this very low value of polarity indicates the deep immersion into membrane in the region of alkyl chains of fatty acids (Figure 4). For W19 variant, the $\mathrm{N}^{*} / \mathrm{T}^{*}$ ratio is much

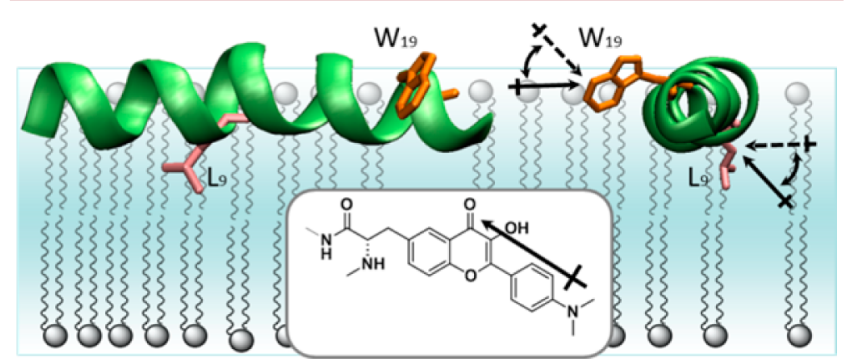

Figure 4. Model of melittin insertion and orientation in the lipid membrane (front and side views). The conformation of the peptide is reported elsewhere. ${ }^{34}$ The curved double arrows show the expected orientational freedom for the AFaa fluorophore, where the hydrated species (dotted arrows) are shallower in the bilayer than the nonhydrated ones (solid arrows). We assume that the orientation of transition dipole moment in AFaa fluorophore is the same for these two species.

larger (1.14) and corresponds to $\varepsilon \approx 20$, indicating that W19 position is much more water exposed, close to the lipid/water interface. The $\mathrm{N}$-terminal label connected through a flexible linker (MFL) shows intermediate $\mathrm{N}^{*} / \mathrm{T}^{*}$ ratio value $(0.70)$ with $\varepsilon \approx 10$, which in line with our previous report ${ }^{28}$ suggests dye localization in the region of the ester groups of phospholipids. Our data are consistent with the current models of melittin in the lipid bilayer, since for both vertical and horizontal orientation of the $\alpha$-helix, the L9 residue is assumed to protrude into the bilayer, while the $\mathrm{W} 19$ residue, placed next to charged amino acids, is expected to localize at the interface. Such interfacial localization of Trp has been reported for many other membrane binding peptides. ${ }^{53}$ Thus, both L9- and W19labeled peptides show similar insertion to the native one, which is probably because in both cases the hydrophobic amino acids ( $\mathrm{L}$ and $\mathrm{W}$ ) were replaced with a hydrophobic AFaa.

Remarkably, addition of cholesterol to the lipid bilayers induces only minor changes in the dual emission of L9- and W19-labeled peptides (Figure 3B). Deconvolution analysis shows that the $\mathrm{N}^{*} / \mathrm{T}^{*}$ ratio is nearly the same for L9 $(0.26)$ and only marginally increased for W19 peptide variant (1.34). In contrast, the $\mathrm{N}$-terminal label exhibits 2 -fold decrease in the $\mathrm{N}^{*} / \mathrm{T}^{*}$ ratio (to 0.36 ), indicating a strong decrease in the environment polarity of the label. As in the N-terminal labeled melittin the $3 \mathrm{HF}$ dye is connected to the peptide through a flexible linker, we speculate that cholesterol directs the probe deeper into the bilayer, independently from the peptide. Therefore, fluorescent amino acid AFaa (in L9 and W19 positions) is far better than the $\mathrm{N}$-terminal probe for studying insertion of the peptide into the membranes due to rigid connection to the backbone.

Finally, we recorded the fluorescence spectra of the labeled melittin peptides added to suspensions of live HeLa cells. The spectra show the same trends as for model membranes (Figure
$3 C)$, suggesting that the insertion of melittin into cell plasma membranes should be similar to the model systems.

Determination of Peptide Orientation in Membrane. The amphiphilic helix of melittin could lay parallel to the membrane surface on the water/lipid interface or form pores with transmembrane orientation perpendicular to the surface. These two possible conformations could be discriminated using AFaa-labeled melittins and fluorescence microscopy with a polarized light source, to selectively excite fluorophores that are oriented parallel to the polarization plane of the light. ${ }^{47,54}$ Since the AFaa amino acid is structurally close to a natural aromatic amino acid, its fluorophore should be oriented almost perpendicular to the $\alpha$-helix. Moreover, according to NMR data, ${ }^{34}$ the W19 and L9 lateral chains in the $\alpha$-helix of melittin are oriented almost perpendicular to each other (Figure 4). Therefore, if melittin $\alpha$-helix is oriented perpendicular to the membrane plane, both L9 and W19 labels will be oriented parallel to the membrane plane. In contrast, a parallel orientation of the melittin $\alpha$-helix to the membrane plane will result in opposite orientations of W19 and L9 with respect to the membrane plane (Figure 4).

We performed two-photon excitation microscopy of melittin bound to DOPC giant unilamellar vesicles (GUVs) (Figure 5A). The polarized two-photon light source allows photoselection of the fluorophores when their transition dipole is parallel to the direction of the light polarization. ${ }^{47,54}$ The emission of the $\mathrm{N}^{*}$ and $\mathrm{T}^{*}$ species of AFaa was recorded in the blue $(480-565 \mathrm{~nm})$ and red $(>565 \mathrm{~nm})$ channels, respectively. According to our previous studies, the $\mathrm{T}^{*}$ emission is directly linked to the nonhydrated species of the dye, while the $\mathrm{N}^{*}$ emission corresponds to a mixture of nonhydrated and hydrated species. ${ }^{45}$ The hydrated species usually exhibit a shallower location and therefore a somewhat different orientation with respect to the nonhydrated species. ${ }^{47}$ Our results show that for the L9-labeled melittin, the effect of selective excitation by the polarized light is observed mostly for the blue channel, as shown by the bright emission of the vesicle at its equator region (Figure $5 \mathrm{~A} 1$ ). As a result, the higher values of the blue/red ratios in the ratiometric image correspond to the equator region of GUVs (Figure $5 \mathrm{~A} 3$ ). Assuming the same orientation of the transition dipole moments in AFaa fluorophore for hydrated and nonhydrated species, the observed differences in the photoselection profiles suggest that these two species are oriented differently in the bilayer. We can conclude that the orientation of AFaa fluorophore in L9-position varies from titled for nonhydrated species until horizontal closer to the bilayer surface for the hydrated species (Figure 4). In contrast, the W19 melittin analogue shows exactly the opposite behavior, since the effect of light polarization is observed only for the red channel, with a clear photoselection for the equator region of the GUVs (Figure $5 \mathrm{~B} 2$ ). As a consequence, in the ratio images, the color contrast appears opposite to that of L9 melittin (Figure 5 B3). Thus, for the W19 melittin, the orientation of AFaa fluorophore varies from horizontal for the nonhydrated species to tilted toward the bilayer surface for the hydrated species (Figure 4). Consequently, the L9 and W19 positions of melittin differ drastically not only by the insertion of the $3 \mathrm{HF}$ fluorophore, but also by its orientation in the lipid bilayer. The fact that L9 and W19 derivatives show different behaviors strongly suggests that their orientation in the bilayer is imposed by the melittin peptide. Taken together, these data support a parallel orientation of the melittin to the membrane surface, ${ }^{55}$ where 


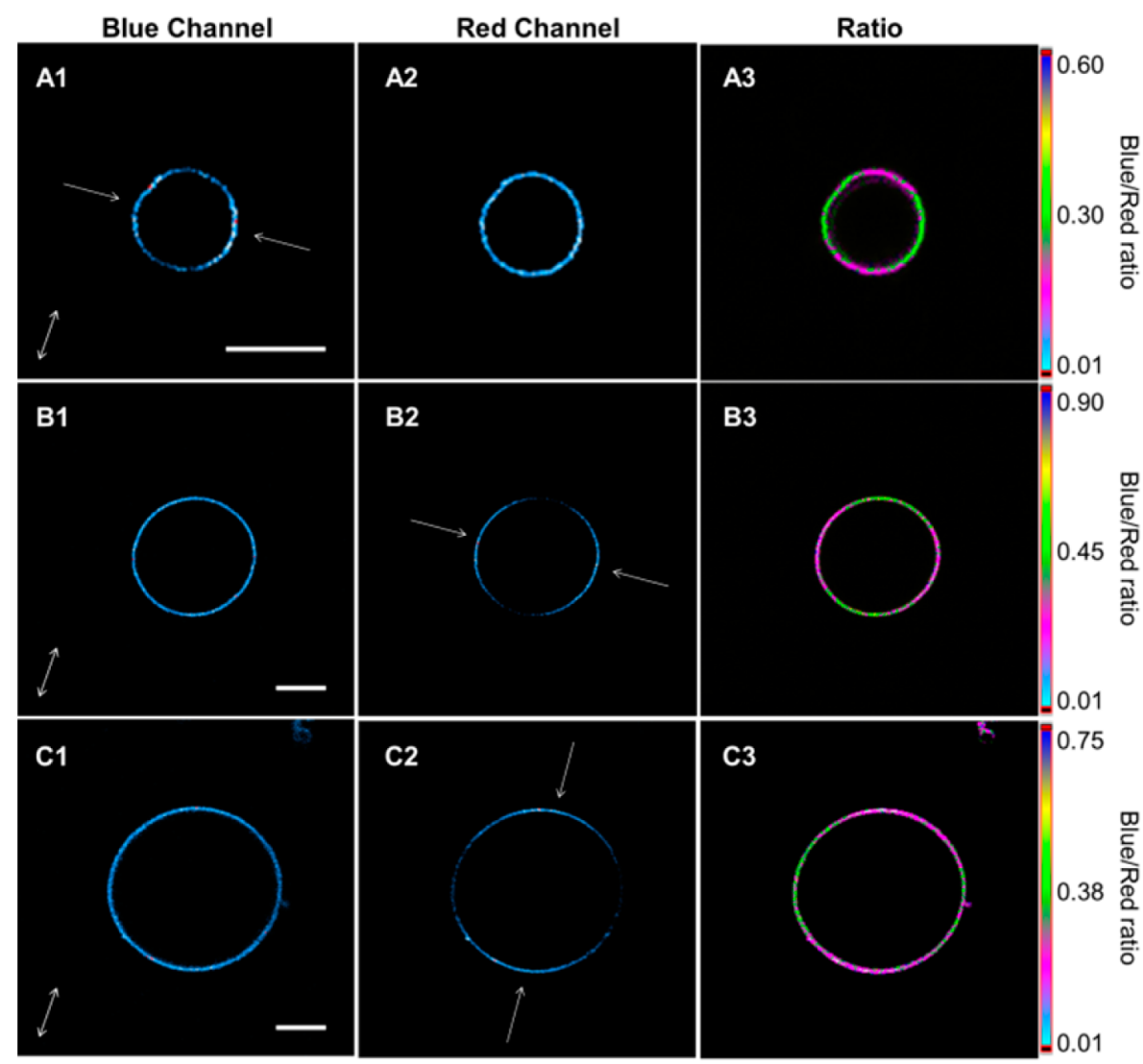

Figure 5. Two-photon fluorescence microscopy images of L9 (A), W19 (B), and N-terminal (C) labeled melittin bound to DOPC GUVs. The images were recorded at the blue channel (A1, B1, and $\mathrm{C} 1$ ) and red channel (A2, B2, and $\mathrm{C} 2)$. Then, the blue/red ratio images were calculated (A3, B3, and C3). The color of each pixel of these ratio images represents the $I_{\text {blue }} / I_{\text {red }}$ intensity ratio, while the pixel intensity corresponds to the total intensity at both channels. Two-photon excitation wavelength was at $830 \mathrm{~nm}$. Double-headed arrows indicate the orientation of light polarization, while other arrows indicate the photoselection areas. Scale bar is $10 \mu \mathrm{m}$. Concentration of melittin was $0.2 \mu \mathrm{M}$.
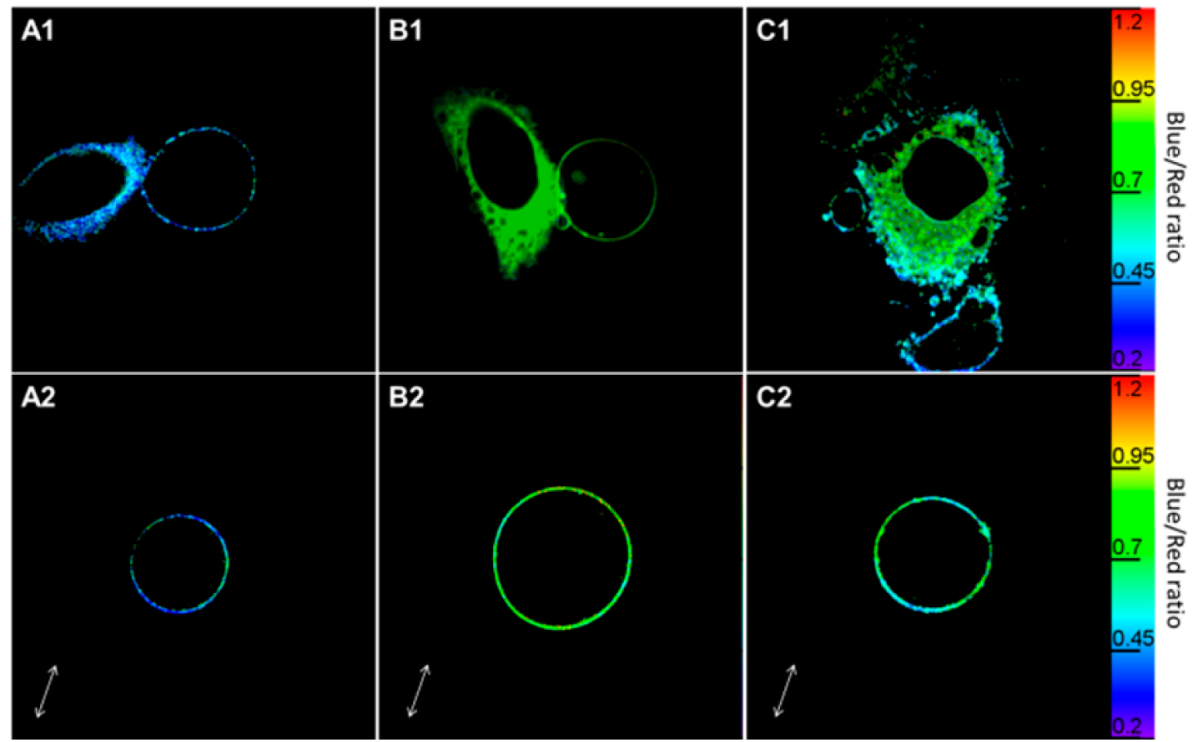

Figure 6. Two-photon fluorescence microscopy images of HeLa cells stained with L9 (A), W19 (B), and N-terminal (C) labeled melittin. The upper panels $(\mathrm{A} 1-\mathrm{C} 1)$ represent typical cells generating vesicles in the presence of melittin, while the lower panels $(\mathrm{A} 2-\mathrm{C} 2)$ show selected images of the produced vesicles. The color of each pixel represents the value of the intensity ratio $I_{\text {blue }} / I_{\text {red }}$, while the pixel intensity corresponds to the total intensity at both channels. Double-headed arrows indicate the orientation of the light polarization. Two-photon excitation wavelength was at 830 $\mathrm{nm}$. Sizes of the images were $70 \times 70 \mu \mathrm{m}^{2}$. Peptide concentration was $1 \mu \mathrm{M}$.

the L9 and W19 residues present different orientations relative to the surface (Figure 4). Our results are consistent with recent 
$\mathrm{EPR}^{38}$ and oriented circular dichroism studies ${ }^{56}$ showing that most of the melittin $\alpha$-helix stays parallel to the surface upon binding to lipid membranes.

Finally, the data of the N-terminal labeled melittin suggest that orientation of $3 \mathrm{HF}$ fluorophore varies from vertical for the nonhydrated species to tilted toward the membrane surface for the hydrated species, in line with our previous studies. ${ }^{28}$ However, fluorescence of the N-terminal labeled melittin does not provide a clear information about the peptide orientation, as its fluorophore is connected to the peptide through a flexible linker. As a consequence, its nonhydrated species tends to orient vertically in the bilayer, as is observed for membrane probes based on this fluorophore. ${ }^{45,47}$

Next, the same approach was applied to determine the melittin orientation in cell membranes. Since melittin is a membrane active peptide, it leads even at $1 \mu \mathrm{M}$ concentration to the disruption of the plasma membrane of HeLa cells and formation of micrometer-scale vesicles (Figure 6), which originate from the plasma membranes. Microscopy images of these vesicles clearly show the effects of light polarization, which are the same as those observed for GUVs (Figure 5). Thus, the orientation of AFaa dye at L9 and W19 positions of melittin in the plasma membranes is similar to that in the model lipid bilayers. Such orientation of the labels can be realized only when melittin $\alpha$-helix binds parallel to the cell membrane surface and does not adopt transmembrane orientation. Thus, using the new amino acid, for the first time to our knowledge, we were able to register the orientation of melittin in natural membranes, and show that it is the same as in model membranes.

\section{CONCLUSION}

A new fluorescent L-amino acid (AFaa) bearing an environment-sensitive 3-hydroxychromone fluorophore as a side chain was synthesized and introduced into the melittin peptide at two alternative positions by solid-phase synthesis. The structure of AFaa is derived from the L-tyrosine amino acid, which confers a well-defined orientation of the fluorophore in respect to the peptide $\alpha$-helix and ensures the close location of the fluorophore to the peptide backbone, in contrast to standard labeling approaches through a flexible linker. These attractive features were successfully used to determine the insertion and orientation of the labeled melittin peptide in lipid bilayers. Our spectroscopy and microscopy data suggested that melittin is preferentially oriented parallel to the bilayer surface in model and natural (cellular) membranes. The developed amino acid and proposed methodology will be of interest to study other membrane peptides.

\section{ASSOCIATED CONTENT}

\section{S Supporting Information}

Additional characterization data on the fluorescent amino acid and melittin peptides are presented. This material is available free of charge via the Internet at http://pubs.acs.org.

\section{AUTHOR INFORMATION}

\section{Corresponding Author}

*E-mail: andrey.klymchenko@unistra.fr; fax: (+33) 368854313.

\section{Author Contributions}

The manuscript was written through contributions of all authors. All authors have given approval to the final version of the manuscript. Viktoriia Y. Postupalenko and Oleksandr M. Zamotaiev contributed equally.

\section{Notes}

The authors declare no competing financial interest.

\section{ACKNOWLEDGMENTS}

V.Y.P., O.M.Z, V.G.P., and this work were supported by ANR Fluoaant, ANR Femtostack, ANR Fluometadn, ANR Cellmemprobes, CNRS, and Université de Strasbourg. O.V.S. was supported by ARCUS Alsace. We thank Cyril Antheaume and Patrick Wehrung for NMR and mass measurements, respectively.

\section{REFERENCES}

(1) Almeida, P. F., and Pokorny, A. (2012) 5.10 Interactions of Antimicrobial Peptides with Lipid Bilayers, In Comprehensive Biophysics (Edward, H. E., Ed.) pp 189-222, Elsevier, Amsterdam.

(2) Seelig, J. (2004) Thermodynamics of lipid-peptide interactions. Biochim. Biophys. Acta 1666, 40-50.

(3) Strandberg, E., and Ulrich, A. S. (2004) NMR methods for studying membrane-active antimicrobial peptides. Concepts in Magnetic Resonance Part A 23A, 89-120.

(4) Mäler, L. (2013) Solution NMR studies of cell-penetrating peptides in model membrane systems. Adv. Drug Delivery Rev. 65, $1002-1011$.

(5) Ladokhin, A., Fernández-Vidal, M., and White, S. (2010) CD spectroscopy of peptides and proteins bound to large unilamellar vesicles. J. Membr. Biol. 236, 247-253.

(6) Klug, C. S., and Feix, J. B. (2008) Methods and Applications of Site-Directed Spin Labeling EPR Spectroscopy, In Methods in Cell Biology (Dr. John, J. C., and Detrich, H. W., III, Eds.) pp 617-658, Academic Press.

(7) Matos, P. M., Franquelim, H. G., Castanho, M. A. R. B., and Santos, N. C. (2010) Quantitative assessment of peptide-lipid interactions.: Ubiquitous fluorescence methodologies. Biochim. Biophys. Acta 1798, 1999-2012.

(8) Loving, G. S., Sainlos, M., and Imperiali, B. (2010) Monitoring protein interactions and dynamics with solvatochromic fluorophores. Trends Biotechnol. 28, 73-83.

(9) Klymchenko, A. S., and Mely, Y. (2013) Fluorescent environment-sensitive dyes as reporters of biomolecular interactions. Prog. Mol. Biol. Transl. Sci. 113, 35-58.

(10) Kim, Y., Ho, S. O., Gassman, N. R., Korlann, Y., Landorf, E. V., Collart, F. R., and Weiss, S. (2008) Efficient site-specific labeling of proteins via cysteines. Bioconjugate Chem. 19, 786-791.

(11) Lohse, J., Nielsen, P. E., Harrit, N., and Dahl, O. (1997) Fluorescein-conjugated lysine monomers for solid phase synthesis of fluorescent peptides and PNA oligomers. Bioconjugate Chem. 8, 503509 .

(12) Mizuno, N., Varkey, J., Kegulian, N. C., Hegde, B. G., Cheng, N., Langen, R, and Steven, A. C. (2012) Remodeling of lipid vesicles into cylindrical micelles by alpha-synuclein in an extended alpha-helical conformation. J. Biol. Chem. 287, 29301-29311.

(13) Itoh, H., Matsuoka, S., Kreir, M., and Inoue, M. (2012) Design, synthesis and functional analysis of dansylated polytheonamide mimic: an artificial peptide ion channel. J. Am. Chem. Soc. 134, 14011-14018.

(14) Haldar, S., Raghuraman, H., and Chattopadhyay, A. (2008) Monitoring orientation and dynamics of membrane-bound melittin utilizing dansyl fluorescence. J. Phys. Chem. B 112, 14075-14082.

(15) Holt, A., Koehorst, R. B., Rutters-Meijneke, T., Gelb, M. H., Rijkers, D. T., Hemminga, M. A., and Killian, J. A. (2009) Tilt and rotation angles of a transmembrane model peptide as studied by fluorescence spectroscopy. Biophys. J. 97, 2258-2266.

(16) Basle, E., Joubert, N., and Pucheault, M. (2010) Protein chemical modification on endogenous amino acids. Chem. Biol. 17, 213-227. 
(17) Cohen, B. E., McAnaney, T. B., Park, E. S., Jan, Y. N., Boxer, S. G., and Jan, L. Y. (2002) Probing protein electrostatics with a synthetic fluorescent amino acid. Science 296, 1700-1703.

(18) Sinkeldam, R. W., Greco, N. J., and Tor, Y. (2010) Fluorescent analogs of biomolecular building blocks: design, properties, and applications. Chem. Rev. 110, 2579-2619.

(19) Katritzky, A. R., and Narindoshvili, T. (2009) Fluorescent amino acids: advances in protein-extrinsic fluorophores. Org. Biomol. Chem. 7, 627-634.

(20) Summerer, D., Chen, S., Wu, N., Deiters, A., Chin, J. W., and Schultz, P. G. (2006) A genetically encoded fluorescent amino acid. Proc. Natl. Acad. Sci. U.S.A. 103, 9785-9789.

(21) Shen, B., Xiang, Z., Miller, B., Louie, G., Wang, W. Y., Noel, J. P., Gage, F. H., and Wang, L. (2011) Genetically encoding unnatural amino acids in neural stem cells and optically reporting voltagesensitive domain changes in differentiated neurons. Stem Cells 29, $1231-1240$.

(22) Lee, H. S., Guo, J., Lemke, E. A., Dimla, R. D., and Schultz, P. G. (2009) Genetic incorporation of a small, environmentally sensitive, fluorescent probe into proteins in Saccharomyces cerevisiae. J. Am. Chem. Soc. 131, 12921-12923.

(23) Loving, G., and Imperiali, B. (2008) A versatile amino acid analogue of the solvatochromic fluorophore 4-N,N-dimethylamino1,8-naphthalimide: a powerful tool for the study of dynamic protein interactions. J. Am. Chem. Soc. 130, 13630-13638.

(24) Strizhak, A. V., Postupalenko, V. Y., Shvadchak, V. V., Morellet, N., Guittet, E., Pivovarenko, V. G., Klymchenko, A. S., and Mely, Y. (2012) Two-color fluorescent l-amino acid mimic of tryptophan for probing peptide-nucleic acid complexes. Bioconjugate Chem. 23, 24342443.

(25) Sengupta, P. K., and Kasha, M. (1979) Excited state protontransfer spectroscopy of 3-hydroxyflavone and quercetin. Chem. Phys. Lett. 68, 382-385.

(26) Zamotaiev, O. M., Postupalenko, V. Y., Shvadchak, V. V., Pivovarenko, V. G., Klymchenko, A. S., and Mely, Y. (2011) Improved hydration-sensitive dual-fluorescence labels for monitoring peptidenucleic acid interactions. Bioconjugate Chem. 22, 101-107.

(27) Demchenko, A. P., Mely, Y., Duportail, G., and Klymchenko, A. S. (2009) Monitoring biophysical properties of lipid membranes by environment-sensitive fluorescent probes. Biophys. J. 96, 3461.

(28) Postupalenko, V. Y., Shvadchak, V. V., Duportail, G., Pivovarenko, V. G., Klymchenko, A. S., and Mely, Y. (2011) Monitoring membrane binding and insertion of peptides by twocolor fluorescent label. Biochim. Biophys. Acta 1808, 424-432.

(29) Shvadchak, V. V., Falomir-Lockhart, L. J., Yushchenko, D. A., and Jovin, T. M. (2011) Specificity and kinetics of alpha-synuclein binding to model membranes determined with fluorescent excited state intramolecular proton transfer (ESIPT) probe. J. Biol. Chem. 286, 13023-13032.

(30) Shynkar, V. V., Klymchenko, A. S., Kunzelmann, C., Duportail, G., Muller, C. D., Demchenko, A. P., Freyssinet, J. M., and Mely, Y. (2007) Fluorescent biomembrane probe for ratiometric detection of apoptosis. J. Am. Chem. Soc. 129, 2187-2193.

(31) Dziuba, D., Postupalenko, V. Y., Spadafora, M., Klymchenko, A. S., Guerineau, V., Mely, Y., Benhida, R., and Burger, A. (2012) A universal nucleoside with strong two-band switchable fluorescence and sensitivity to the environment for investigating DNA interactions. J. Am. Chem. Soc. 134, 10209-10213.

(32) Yushchenko, D. A., Fauerbach, J. A., Thirunavukkuarasu, S., Jares-Erijman, E. A., and Jovin, T. M. (2010) Fluorescent ratiometric MFC probe sensitive to early stages of alpha-synuclein aggregation. J. Am. Chem. Soc. 132, 7860-7861.

(33) Nemkovich, N. A., Kruchenok, J. V., Rubinov, A. N., Pivovarenko, V. G., and Baumann, W. (2001) Site selectivity in excited-state intramolecular proton transfer in flavonols. J. Photochem. Photobiol., A 139, 53-62.

(34) Sosa, L. D., Alfaro, E., Santiago, J., Narvaez, D., Rosado, M. C., Rodriguez, A., Gomez, A. M., Schreiter, E. R., and Pastrana-Rios, B.
(2011) The structure, molecular dynamics, and energetics of centrinmelittin complex. Proteins 79, 3132-3143.

(35) Raghuraman, H., and Chattopadhyay, A. (2007) Melittin: a membrane-active peptide with diverse functions. Biosci. Rep. 27, 189223.

(36) Hall, K., Lee, T. H., and Aguilar, M. I. (2011) The role of electrostatic interactions in the membrane binding of melittin. J. Mol. Recognit. 24, 108-118.

(37) Toraya, S., Nishimura, K., and Naito, A. (2004) Dynamic structure of vesicle-bound melittin in a variety of lipid chain lengths by solid-state NMR. Biophys. J. 87, 3323-3335.

(38) Gordon-Grossman, M., Gofman, Y., Zimmermann, H., Frydman, V., Shai, Y., Ben-Tal, N., and Goldfarb, D. (2009) A combined pulse EPR and Monte Carlo simulation study provides molecular insight on peptide-membrane interactions. J. Phys. Chem. B $113,12687-12695$.

(39) Raghuraman, H., and Chattopadhyay, A. (2007) Orientation and dynamics of melittin in membranes of varying composition utilizing NBD fluorescence. Biophys. J. 92, 1271-1283.

(40) Park, S. C., Kim, J. Y., Shin, S. O., Jeong, C. Y., Kim, M. H., Shin, S. Y., Cheong, G. W., Park, Y., and Hahm, K. S. (2006) Investigation of toroidal pore and oligomerization by melittin using transmission electron microscopy. Biochem. Biophys. Res. Commun. 343, 222-228.

(41) Krauson, A. J., He, J., and Wimley, W. C. (2012) Determining the mechanism of membrane permeabilizing peptides: Identification of potent, equilibrium pore-formers. Biochim. Biophys. Acta 1818, 16251632.

(42) Hufford, C. D., Oguntimein, B. O., and Shoolery, J. N. (1987) Angoluvarin, an antimicrobial dihydrochalcone from uvaria-angolensis. J. Org. Chem. 52, 5286-5288.

(43) Chen, C., Zhu, Y. F., and Wilcoxen, K. (2000) An improved synthesis of selectively protected L-Dopa derivatives from L-tyrosine. J. Org. Chem. 65, 2574-2576.

(44) Chou, P. T., Martinez, M. L., and Clements, J. H. (1993) Reversal of excitation behavior of proton-transfer vs charge-transfer by dielectric perturbation of electronic manifolds. J. Phys. Chem. 97, $2618-2622$.

(45) Klymchenko, A. S., Mely, Y., Demchenko, A. P., and Duportail, G. (2004) Simultaneous probing of hydration and polarity of lipid bilayers with 3-hydroxyflavone fluorescent dyes. Biochim. Biophys. Acta $1665,6-19$.

(46) Fidorra, M., Duelund, L., Leidy, C., Simonsen, A. C., and Bagatolli, L. A. (2006) Absence of fluid-ordered/fluid-disordered phase coexistence in ceramide/POPC mixtures containing cholesterol. Biophys. J. 90, 4437-4451.

(47) Klymchenko, A. S., Oncul, S., Didier, P., Schaub, E., Bagatolli, L., Duportail, G., and Mely, Y. (2009) Visualization of lipid domains in giant unilamellar vesicles using an environment-sensitive membrane probe based on 3-hydroxyflavone. Biochim. Biophys. Acta 1788, 495499.

(48) Clamme, J. P., Azoulay, J., and Mély, Y. (2003) Monitoring of the formation and dissociation of polyethylenimine/DNA complexes by two photon fluorescence correlation spectroscopy. Biophys. J. 84, 1960-1968.

(49) Darwich, Z., Kucherak, O. A., Kreder, R., Richert, L., Vauchelles, R, Mély, Y., and Klymchenko, A. S. (2013) Rational design of fluorescent membrane probes for apoptosis based on 3-hydroxyflavone. Meth. Appl. Fluoresc. 1, 025002.

(50) Shapovalov, M. V., and Dunbrack, R. L., Jr. (2011) A smoothed backbone-dependent rotamer library for proteins derived from adaptive kernel density estimates and regressions. Structure 19, 844858.

(51) Terwilliger, T. C., and Eisenberg, D. (1982) The structure of melittin. II. Interpretation of the structure. J. Biol. Chem. 257, 60166022.

(52) Griffith, O. H., Dehlinger, P. J., and Van, S. P. (1974) Shape of the hydrophobic barrier of phospholipid bilayers (evidence for water penetration in biological membranes). J. Membr. Biol. 15, 159-192. 
(53) Ulmschneider, M. B., Sansom, M. S., and Di Nola, A. (2005) Properties of integral membrane protein structures: derivation of an implicit membrane potential. Proteins 59, 252-265.

(54) Bagatolli, L. A. (2006) To see or not to see: lateral organization of biological membranes and fluorescence microscopy. Biochim. Biophys. Acta 1758, 1541-1556.

(55) Svensson, F. R., Lincoln, P., Nordén, B., and Esbjörner, E. K. (2011) Tryptophan orientations in membrane-bound gramicidin and melittin-a comparative linear dichroism study on transmembrane and surface-bound peptides. Biochim. Biophys. Acta 1808, 219-228.

(56) Krauson, A. J., He, J., and Wimley, W. C. (2012) Gain-offunction analogues of the pore-forming peptide melittin selected by orthogonal high-throughput screening. J. Am. Chem. Soc. 134, 1273212741 . 